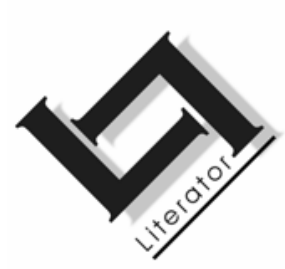

\title{
Vos, Faust, Voss, $\Phi \omega$ s: raakpunte tussen Vos deur Anna M. Louw en enkele ander tekste
}

\author{
Philip John \\ Departement Afrikaans en Nederlands \\ Skool vir Tale, Media en Kommunikasie \\ Nelson Mandela Metropolitaanse Universiteit \\ PORT ELIZABETH \\ E-pos: pjohn@cybertrade.co.za
}

\section{Abstract \\ Vos, Faust, Voss, $\Phi \omega$ s: Points of contact between Vos by Anna M. Louw and selected other texts}

This article explores points of contact between "Vos" by Anna M. Louw and a number of related texts, including the following: the book "Job" from the Christian Bible, "Faust" by Goethe, "Voss" by Patrick White and texts forming part of the Gnostic tradition. The analysis describes similarities and differences, arguing that the implication of the points of contact between the various texts is that Vos suggests that the heritage of the Christian Reformation is not adequate for an understanding of life in South Africa, and it has to be supplemented with perspectives from other traditions.

\section{Opsomming}

Vos, Faust, Voss, $\Phi \omega$ s: Raakpunte tussen Vos deur Anna M. Louw en enkele ander tekste

Hierdie artikel verken die raakpunte tussen "Vos" deur Anna M. Louw en enkele ander tekste, soos die Bybelboek "Job", "Faust" deur Goethe, "Voss" deur Patrick White en tekste uit die tradisie van die gnostiek. Ooreenkomste en verskille word beskryf, en daar word betoog dat die raakpunte tussen die onderskeie tekste die implikasie dra dat Vos suggereer die erfenis van die Christelike Hervorming is onvoldoende as basis vir insig in die bestaan in Suid-Afrika en dat dit aangevul moet word met perspektiewe uit ander tradisies. 
If thou would'st see the Devil, look at thine own self.

Charles Manson

\section{Inleiding}

By 'n roman wat die titel "Vos" dra, behoort die leser vanaf die buiteblad op sy of haar hoede te wees. Dit is nie net dat dié titel uiters evokatief is en van die belangrikste tekste in die Europese literatuurgeskiedenis oproep, soos Van den Vos Reynarde, Goethe se Faust en Voss deur Patrick White nie. Die blote verwysing na die vos, of soos dié dier in Suid-Afrika bekend staan, die jakkals, behoort die leser daarop bedag te maak dat dit 'n teks is wat die leser waarskynlik op ongewone en onverwagte lees- en betekenispaaie sal neem.

In 'n sekere sin is so iets nie onverwags by 'n teks deur Anna M. Louw nie. Nie net het velerlei van haar tekste iets "ongrypbaars" aan hulle nie, maar in baie opsigte is haar oeuvre as geheel van so 'n aard dat 'n sluitende oordeel daaroor en 'n kensketsing daarvan uiters moeilik, indien nie onmoontlik, is nie. Die motief van die "godesnar" wat gebruiklik met haar werk in verband gebring word, druk wel iets uit van die ongrypbare, paradoksale aard van baie van haar werk (Van Zyl, 1990:98-99, 110).

Ofskoon hierdie artikel nie direk fokus op die godesnar-motief nie, lewer dit hopelik wel 'n bydrae tot insig in die rol wat hierdie motief in Louw se werk speel, spesifiek deur 'n fokus op 'n aantal tekste wat met haar laaste roman, Vos (1999), geassosieer kan word. Die betrokke tekste is die Bybelboek Job, Faust deur Goethe, Voss deur Patrick White en geskrifte behorende tot die gnostiek en die apokriewe.

\section{Job}

Die eerste teks wat baie Afrikaanse lesers met Vos in verband sal bring, is waarskynlik die Bybelboek Job. Van die ander tekste wat hier ter sprake kom, is dit die enigste teks wat in die roman as sodanig genoem word (p. 21, 96). Job vervul 'n interessante funksie met betrekking tot Vos. Dit is tegelykertyd die mees belangrike én mins belangrike teks betreffende die rol wat dit speel by betekenisgewing vir die leser van Vos. In baie opsigte lyk Vos soos 'n radikale herskrywing van Job, waarin baie van die gedagtes en sienings wat gebruiklik met Job geassosieer word, op hul kop gekeer word. 
Op 'n basiese vlak ís daar natuurlik 'n ooreenkoms: sowel Job as Vos se wêrelde kan as pastoraal en patriargaal beskryf word, aangesien hulle albei boere is. Hulle het ook gesinne - vrou en kinders. Albei se verhale begin met teenspoed, maar eindig op 'n positiewe noot. Hier kan egter 'n eerste verskil aangedui word. Job se verhaal begin met hom in 'n gunstige situasie (baie besittings, nasate) wat versteur word deur die werking van die Bose. Aan die einde van die boek, voor Job se dood, word die gunstige materiële omstandighede herstel waarmee hy die verhaal begin het: sy besittings vermeerder en hy kry kinders terug (Job 42:10-12). In Vos se geval word die teenspoed wat hy aan die begin van sy verhaal ervaar, ook omgekeer, maar dan nie in 'n materiële sin nie. Vos se herstel kom in sy geestelike of spirituele redding.

Wat egter die duidelikste aanduiding gee van hoe ver die wêrelde van Job en Vos van mekaar verwyder is, is die uitbeelding van die Bose (die Duiwel) in die twee tekste. In Job het die Duiwel direk kontak met God, terwyl hy geen direkte kontak met Job het nie. Job ervaar die Duiwel slegs in die vorm van die teenspoed en rampe wat hom te beurt val en kry nooit te make met die Duiwel in 'n antropomorfiese gestalte nie. Daar word ook nie 'n band gelê tussen die Duiwel en Job se psige of persoonlikheid nie - sy dwalinge is bloot menslik en word nie met die Bose as sodanig in verband gebring nie. Die teenspoed wat hom te beurt val, het ook geen verband met sy psige of persoonlikheid nie (behalwe natuurlik dat hy 'n "model"-gelowige is, wat hom 'n teiken maak vir die Bose (vergelyk Job 1:1).

In Vos is dit heel anders gesteld: Vos het direkte kontak met die Duiwel (die Bose) wat in 'n menslike gestalte manifesteer en God blyk grootliks afwesig te wees. Die Duiwel verskyn sowel as "Teenwoordigheid" van wie Hendrik Vos op bepaalde oomblikke bewus word en met wie hy kommunikeer én in 'n psigies geïnternaliseerde vorm. Tydens een van die hoogtepunte van Vos se interaksie met die magte van die boosheid, verskyn die Duiwel byvoorbeeld in die gedaante van 'n NG-ouderling. Terwyl Vos met hierdie entiteit 'n pakt (verdrag) aangaan onder leiding van die Boesman, Hans Doekvoet, dink hy onthuts dat hierdie verteenwoordiger van die Bose soos hyself lyk (p. 69-70). Duiwel en mens skuif as 't ware oor mekaar en kan nie werklik van mekaar geskei word nie. Die Duiwel verskyn hier dus geïnternaliseer in die psige van 'n mens (karakter).

Dat die Bose 'n duideliker en konkreter gestalte het in Vos as in Job, is in 'n sekere opsig heeltemal te verwagte. Volgens die Christelijke 
encyclopædie voor het Nederlandsche volk (derde deel) kan die uitbeelding van Satan gebruik word om Bybelboeke (soos Job) te dateer, aangesien die uitbeelding 'n ontwikkeling deurgegaan het vanaf die abstrakte na die konkrete. Verwysings na die mag wat mense na sonde beweeg, vind eers plaas met verwysing na ' $n$ "gees" "zonder dat echter duidelijk wordt in hoeverre deze "booze geest' los van Jahwe moet worden bedacht" (Grosheide et al., 1925:182). In die latere tyd waarin Job geskryf is ("de tweede helft van den Koningstijd"), word die Bose benoem met 'n soortnaam, "de tegenstander" en eers in 1 Kronieke 21:1 kry hy die naam Satan.

Die uitbeelding van die Duiwel en die Bose in Vos maak met verwysing na ten minste nog twee kwessies duidelik hoe groot die "afstand" tussen Job en Vos is. Die eerste hou verband met die manier waarop Vos aansluit by 'n reeks pre- en vroeg-Christelike gedagtestrominge, naamlik die Gnostiek. So 'n aansluiting sou impliseer dat Job 'n onvoldoende basis bied vir die verkenning van die onderwerp waarmee Vos gemoeid is en dat dit aangevul moet word met bykomende materiaal. Die tweede het te make met die sienings en waardes wat geassosieer word met die opkoms van die Europese burgerlike (post-Christelike) samelewing - 'n aspek wat in die volgende afdeling ter sprake kom.

Een van die basiese uitgangspunte van die Gnostiek, is dat die materiële heelal nie deur God geskape is nie, maar deur die tussenkoms van 'n demoniese demiurg wat in sekere tekste die naam laldabaōth dra. Dit is een van die name wat die gnostici gegee het aan die "jaloerse" God waarna in die Bybelboek Genesis verwys word. Die wêreld wat dié entiteit skep, is 'n kopie van die perfekte spirituele gedeelte van die heelal wat deur God geskape is, met die verskil dat die tekortkominge van dié "sekondêre skepper", die demiurg, afwykings veroorsaak. Dit is hierdie afwykings wat verantwoordelik is vir die sonde, lyding - alles wat benoem word met die term, die Bose. Slegs 'n beperkte aantal mense - die gnostici is in staat om te onderskei tussen die afwykings en die oorspronklike perfekte skepping. Wanneer hierdie mag of wysheid korrek gebruik word deur die gnostikus kan hy of sy die beperkinge van die materiële oorstyg en herenig word met God (Layton, 1987:15-18; Doresse, 1960:258).

Dit is duidelik dat so ' $n$ siening aansluit by die uitbeelding van die wêreld in Vos, waar die wêreld verlate van God is en die duiwelse "Grootbaas" heers (p. 55-56, 66). Hy word ook die "Prins van hierdie wêreld" genoem in die teks (p. 92) - 'n benaming wat algemeen 
voorgekom het in Gnostiese tekste. Die Boesman, Hans Doekvoet, wat Vos help in sy strewe om kontak te maak met hierdie ondermaanse heerser, het klaarblyklik ook 'n skare demoniese entiteite, die dsaos en die gagarob, onder sy beheer (p. 55). Hiermee word die "ongoddellike" aard van die fisiese wêreld beklemtoon.

Dié uitbeelding staan duidelik baie ver van die wêreld van Job. Job bevestig primêr die almag van die God van die Ou Testament - ook wat betref die ondermaanse, soos die lewe en wêreld van die mens, Job. In Job word die mens gered deur sy geloof in God, sy gehoorsaamheid en sy bereidwilligheid om hom neer te lê by die wette van God. Dit maak nie soseer saak wat sy dade is nie, solank as hy net bly glo. Alles word beskik deur God en die mens hoef net bloot te gehoorsaam en veral gelowig te bly (vgl. Job 35:2-8).

In die Gnostiese uitkyk - en in Vos - is dit duidelik dat individuele handeling voorop staan, gefokus op "gnosis". In die Gnostiese ideëstelsel word verlossing geassosieer met individuele handeling (soos ook verder toegelig word in hierdie artikel, met verwysing na die gnostiese "man van lig"). In Vos is dit duidelik - ten minste vanuit die perspektief van die karakter, Hendrik Vos - dat hulp nie van 'n afwesige en afsydige God te verwagte is nie en dat Hendrik self die inisiatief moet neem as hy sy situasie wil verbeter.

Om Job dus met Vos in verband te bring, is om aan te dui dat Job nie (of nie meer) 'n gepaste benadering tot die werklikheid bied nie. Vos is in hierdie opsig 'n "spieëlbeeld" van Job, in die sin dat alles daarin in 'n omgekeerde vorm teenwoordig is: Vos word, soos Job, met teenspoed getref, maar God is afwesig en nie van nut vir Vos in sy pogings om sy verlossing te bewerkstellig nie. Daarvoor moet hy hom wend tot magte wat met die aarde geassosieer word. Hy kan hom ook nie (meer) net verlaat op geloof en bloot glo nie, maar moet die inisiatief neem en handel.

Dié "omkering" het belangrike implikasies vir die leser van Vos. Met die relativering of opsyskuiwing van Job word gesuggereer dat die konseptuele skemas waarmee die leser waarskynlik gewoonlik die wêreld verstaan het, nie voldoende is nie. 'n Nog belangriker implikasie is dat aansluiting by gedagtes en idees wat uit die bewussyn en kulturele erfenis geweer is - apokriewe tekste en die voorstellings van die gnostiek - nodig is om die wêreld beter te 
verstaan. ${ }^{1}$ Vos kan dus gelees word as kritiek op die beperking van die bewussyn binne die grense van 'n Reformatoriese perspektief. Anders gestel, dit is 'n teks wat die leser daarop bedag (kan) maak dat hy of sy "gekondisioneer" is.

Die groter klem op individuele handeling en 'n "oper" bewussyn waarop Vos sinspeel, wat so ver verwyder is van die Job-wêreld, sluit egter duidelik aan by nog 'n ideëstelsel, benewens die Gnostiese, naamlik dié geassosieer met die Europese burgerlike wêreld. Om meer insig in hierdie sy van die roman te kry, moet die aandag verskuif na Goethe se drama, Faust.

\section{Faust}

'n Eerste regverdiging om Goethe se drama met Vos in verband te bring, is 'n aantal oppervlakkige ooreenkomste, soos die gelyksoortige klank van die titels van die twee tekste en die ooreenkoms tussen die name van die protagoniste: Heinrich in Faust ("Hendrik" in die Afrikaanse vertaling) en Hendrik Vos in Vos. Vos stem ook ooreen met die bou van Faust, deurdat die interaksie tussen Hendrik en Hans, die Boesman, ooreenkom met dié van Faust en Mephistopheles in Faust: in albei tekste is daar eers ' $n$ "verkennende" ontmoeting tussen die mens en 'n duiwelsfiguur, waarna daar tydens 'n hieropvolgende ontmoeting 'n pakt aangegaan word.

Wat benewens hierdie ooreenkomste deurslaggewend is vir ' $n$ verbandlegging, is die rol wat die idee van handeling (die "daad") in Faust en Vos speel, in teenstelling met Job. Baie mense assosieer Faust waarskynlik met die eerste deel van die drama, wat 'n tragiese romanse is (of so verstaan kan word): die verhaal van die verhouding van Faust en Grietjie, Grietjie se ondergang en redding - alles met die hulp van die toenmalige inkarnasie van die duiwel, Mephistopheles. So 'n verskraling van die drama veroorsaak egter dat die betekenis daarvan tot die persoonlike (individuele) beperk bly. Die bybring van die tweede deel maak dit duidelik in watter mate Faust 'n historiese dokument is, wat nie slegs geïnterpreteer moet word met verwysing na die "ewige" menslike nie. Spesifiek die opkoms en triomf van die Europese burgerstand vanaf die

1 Dat so 'n ingesteldheid deel uitmaak van die samestelling van Vos, spreek ook uit die moontlikheid dat daar ' $n$ verband gelê kan word tussen die bo-aardse reise wat Vos onderneem (p. 120-122) en die reise van die profeet Henog in Hoofstukke 17 tot 36 in die apokriewe Boek van Henog (Weich, 1994). 
sewentiende eeu en die kapitalistiese samelewing wat daaruit ontwikkel het, vorm die raamwerk vir interpretasie.

Die pakt of weddenskap wat Faust met Mephistopheles aangaan, is in hierdie verband van deurslaggewende belang. Indien die drama verskraal word na die eerste deel (die verhaal van Faust en Grietjie se liefde), is die pakt tussen Faust en Mephistopheles basies 'n ooreenkoms wat Faust in staat stel om hom los te maak van die greep van die heersende moraliteit en sy luste te laat botvier. So benader, is die drama hoofsaaklik 'n (moralistiese) waarskuwing: kyk wat bring 'n pakt met die duiwel jou in die sak. Die pakt tussen Faust en Mephistopheles lei tot wreedheid en lyding - tot die vernietiging van die (vroulike) onskuld van Grietjie.

Wanneer die tweede deel bygebring word, is hierdie eerste deel egter slegs 'n voorspel. Die tweede deel maak dit baie duidelik dat Faust se tyd - die agtiende en vroeg negentiende eeu - deeglik in die weefsel van die drama opgeneem is. Die pakt wat Faust met Mephistopheles aangaan, is 'n verbeelding van die manier waarop die bourgeois-kultuur fasette van die mens se psigiese samestelling ingespan het om die feodale middeleeuse wêreld na dié van die moderne (kapitalistiese) wêreld te omvorm. Twee tersaaklike ingesteldhede wat Mephistopheles na Faust bring, is in die eerste plek die reedsgenoemde a-moralistiese oriëntasie teenoor die wêreld wat geen beperking aanvaar nie en in die tweede plek 'n aktiewe, produktiewe ingesteldheid teenoor die wêreld, wat die natuur en ander mense sien as middele tot 'n (pragmatiese) doel, asook as roumateriaal om oorheers en "gebruik" te word.

In die "Proloog in die hemel" in Deel 1 beskryf God Mephistopheles in sodanige terme wat klem plaas op sy onbelemmerde daadlus waarmee hy vir Faust moet "inspireer":

DIE HEER: Tree daarin op sonder perk of pen;

Ek het ú gelyke nog nooit gehaat.

Dus gee ek hom [Faust] graag tot metgesel

'n Duiwel, dat hy sy daadlus kan behou (Goethe, 1966:25).

Met die sluiting van die pakt tussen Faust en Mephistopheles word hierdie "duiwelse" daadlus dus na Faust oorgedra, of aan hom beskikbaar gestel. Dié pakt is dan tegelykertyd 'n uitbeelding van, 'n verklaring van en 'n oordeel oor die daadkragtigheid van die Europese bourgeois-samelewing waaruit die moderne wêreld - ons wêreld - tot stand gekom het. 
Dit is ook aan die "daad" dat die uiteindelike geestelike heil of ondergang van Faust gekoppel word in die drama: die pakt wat Faust met Mephistopheles aangaan is dat Mephistopheles hom sal help om sy begeertes te verwerklik, maar dat Mephistopheles sy siel sal kry indien hy ophou strewe:

FAUST: As ék ooit rustig op my rusbank lê, Laat dit dáár en dan klaar wees met my!

As jy ooit met vleitaal my kan belieg,

Sodat ek tevrede myself betrag,

As jy met genieting my kan bedrieg,

Laat dit dan wees my laaste dag!

Dit wed ek! (Goethe, 1966:67).

Terselfdertyd is dit ook aan hierdie daadgerigtheid dat die dilemma van Faust (lees: die bourgeois-mens en -samelewing) se bestaan gekoppel is: om op te hou strewe en op te tree, is om jou siel aan die Bose oor te gee. Om egter aan te hou strewe en op te tree, is om pyn en lyding vir ander te veroorsaak (in Deel 1 is dit treffend beliggaam in die ondergang van Grietjie), 'n siening wat soos volg verwoord word in die drama:

DIE HEER: Die mens sal dwaal solank hy strewe! (Goethe, 1966:25) $)^{2}$

Uiteindelik kan Faust gered word omdat hy nooit ophou strewe en werk het nie. Die Engele wat hom aan die einde van Deel 2 kom haal, stel dit soos volg:

Wer immer strebend sich bemüht,

Den können wir erlösen.

[Hulle wat immer bly strewe, vir hulle kan ons red]

(Goethe, 1808/1833:335; my vertaling, kursief in oorspronklike $-P J)$.

Nog 'n (fassinerende) aspek van die rol wat die strewe en die daad in die bourgeois-wêreld speel, is een wat net sowel uit Marx kon gekom het. Die feit dat die bourgeois geen grens of perk stel aan sy aktiwiteit en ingryping in die wêreld nie, beteken logieserwys dat ook

2 In die Afrikaanse vertaling gaan die idee van "foutering" of sonde, soos wat dit in die oorspronklike is, verlore:

DER HERR: Es irrt der Mensch, solang er strebt (Goethe, 1808/1833:14). 
hyself die objek van sy eie aktiwiteit kan word. In Faust word gewys hoe Faust uiteindelik (onwetend) aan sy eie ondergang en vernietiging werk.

Nadat Faust met blindheid geslaan is deur die heks wat hom besoek, hou hy nie op droom en werk nie en gaan hy voort met die volgende fase van die projek waarmee hy besig is, naamlik die drooglegging van die see en die bou van 'n kanaalstelsel. Wanneer hy Mephistopheles en sy "Lemuriaanse" werkers beveel om voort te gaan en die klank van hul arbeid Faust verbly, word hy inderwaarheid as bedroë en verspot uitgebeeld. Die werkers is nie net besig om aan sy visioenêre kanaalstelsel te werk nie, maar is eintlik besig om sy graf te grawe (Goethe, 1808/1833:268). Mephistopheles verwoord hierdie siening soos volg:

\author{
MEPHISTOPHELES beiseite \\ Du bist doch nur für uns bemüht \\ Mit deinen Dämmen, deinen Buhnen; \\ Denn du bereitest schon Neptunen, \\ Dem Wasserteufel, großen Schmaus. \\ In jeder Art seid ihr verloren: \\ Die Elemente sind mit uns verschworen, \\ Und auf Vernichtung läufts hinaus \\ [Nou werk jy dog net vir ons \\ Met jou damme, jou dyke \\ Berei jy vir die magtige Neptunus, \\ Die Waterduiwel, 'n groot fees. \\ In alle opsigte is jy verlore: \\ Die natuurelemente is aan ons kant \\ En vernietiging wag aan die einde]
}

(Goethe, 1808/1833:323-324; my vertaling - PJ).

So 'n meer inklusiewe lesing van Faust bied 'n manier om die drama met Vos in verband te bring en betekenis aan aspekte van die roman toe te ken, spesifiek aan die "aanpassing" van Faust wat die roman verteenwoordig. Die lesing dui in die eerste plek aan hoeveel belangriker Faust as Job is vir die uitbeelding van die wêreld van Hendrik Vos in Vos.

Hendrik Vos lyk baie meer en tree baie meer op soos Faust as Job. Sowel Faust as Vos begin hul onderskeie verhale in soortgelyke situasies. Faust is onvergenoegd en voel dat die ware lewe hom verbygegaan het terwyl hy hom aan kennis toegewy het. Die pakt wat hy met Mephistopheles aangaan, is dus nie om 'n oorspronklike gunstige situasie, soos in die geval van Job, te herstel nie, maar is daarop gemik om 'n geestelike en ervaringsleemte in sy lewe te vul 
en tot die ontwikkeling van die wêreld by te dra. Vos staan in hierdie opsig aan die een kant wel nader aan Job, omdat hy wel 'n oorspronklike situasie herstel wil hê, naamlik dat die droogte gebreek moet word deur die reën. Aan die ander kant egter weer staan Vos nader aan Faust, aangesien dit duidelik is dat optimale "produksie" op die plaas vir Vos baie belangrik is. Vos is ook, soos Faust, bereid om alle konvensies en waardes oorboord te gooi, solank hy net sy wil en begeerte kan realiseer. Vos, sou mens kon sê, is soos Faust deel van en 'n produk van die Westerse burgerlike samelewing, ingestel op kommoditeitsproduksie en "vooruitgang".

Terwyl daar duidelike aansluitingspunte tussen Faust en Vos is, veral wat betref die rol wat begrippe soos aksie en produksie in die twee tekste speel, is daar egter ook belangrike verskille. Dat daar verskille sou wees, is natuurlik te verwagte, omdat die Duitsland van die agtiende eeu waarin Faust afspeel en die twintigste-eeuse SuidAfrika van Vos verskil. In belangrike opsigte word verskillende stadiums in of vorms van die ontwikkeling van die burgerlike of kapitalistiese leefwyse verteenwoordig. In die eerste plek sou mens kon sê dat Goethe (en Faust) se wêreld veel "burgerliker", oftewel vollediger gemoderniseerd is, as die wêreld van Vos in die SuidAfrika van die dertigerjare. Faust dra duidelik spore van 'n geïndustrialiseerde samelewing, terwyl dit by Vos duidelik nog gaan oor 'n agrariese wêreld, waar landbou, eerder as industriële produksie, dominant is. 'n Proletariaat, in Faust gesuggereer deur die groep "Lemures" wat onder Mephistopheles se aanvoering arbei, is byvoorbeeld nog nie sigbaar in Vos nie. In die geval van Faust sou 'n mens die optrede van die hoofkarakter, Faust, assosieer met 'n tipiese Europese kapitalis; dit kan egter nie gedoen word in die geval van Vos nie. In Vos is dit dus eerder die geval dat die stedelike, bourgeois, industriële, Europese lewensfeer van Faust "vertaal" word tot die ekwivalent daarvan in Suid-Afrika: die blanke Afrikaanse boer.

Met Faust in die agtergrond bied Vos, wanneer die roman soos Faust hierbo benader word, 'n uiters fassinerende blik op die bestaanskondisie van Hendrik Vos, en deur hom, van die blanke Afrikaner. 'n Lesing van Vos deur die "lens" of filter van Faust, bied dus 'n manier om te sien dat die voorstelling in Vos van Hendrik Vos en sy interaksie met die Boesman, Hans Bokpoot, en die natuurlike omgewing eintlik kommentaar lewer op die lewe, bestaan en geskiedenis van die blanke Afrikaner in Suid-Afrika. Waar Faust as die Europese kapitalis en sy aktiwiteite (industrialisering, oorlogvoering, imperialisme) aangebied word as die resultaat van Faust se 
interaksie met 'n verburgerlikte manifestasie van die Bose, Mephistopheles, word dié interaksie in Vos vertaal in die vorm wat dit in die Suid-Afrikaanse konteks aangeneem het.

As hierdie denkwyse logieserwys voortgesit word, suggereer Vos dat die blanke (Afrikaner) in Suid-Afrika sy daaddrif en wil tot oorheersing slegs kon uitleef deur 'n "pakt" met die Bose aan te gaan - met die inheemse Boesmankultuur as bemiddelaar. As gevolg van die pakt wat Vos met Hans Bokpoot aangaan, reën dit op Vos se plaas en is dit vir hom moontlik om suksesvol te boer. Net soos in Faust, gaan hierdie handeling gepaard met nadele. Vos se voorspoed en welvaart duur nie onbepaald voort nie, want "teenmagte" kom geleidelik in werking: Nellie, sy vrou en sy seun, Walther, laat hom alleen op die plaas agter en wanneer hy berou begin ervaar en sy pakt teenoor die Boesman wil opsê, word hy geteister deur 'n reeks rampe, plae en terugslae. Later keer Walther en Nellie weer terug en Nellie laat die dominee, Kossies, kom om die bose geeste uit Vos te dryf. Gedurende die nag nadat die geeste uitgedryf is, brand Alleen se plaashuis onverklaarbaar af, sodat Vos met minder eindig as waarmee hy die roman begin het.

Dit sou gesien kan word as die tragedie van die Afrikaanse boer, naamlik dat hy, soos Faust, deur sy dade lyding en meer positiewe verandering bewerkstellig, maar ook die situasie skep waaraan hy self ondergaan. Soos ook die geval met Faust, sou daar van Vos en die (Afrikaanse) Europese setlaar in Afrika - gesê kan word dat hy deur die Bose uiteindelik tóg ook die goeie in die hand werk, naamlik die skepping van 'n moderne Suid-Afrika.

Uit die mond van Mephistopheles klink hierdie siening soos volg:

MEPHISTOPHELES: 'n Deel van daardie krag is ek, Wat steeds die kwaaie wil, en steeds die goeie wek

(Goethe, 1966:57).

Net soos met Job, sal daar met betrekking tot Faust gesê moet word dat die drama net tot op 'n sekere punt betekenisvol met Vos in verband gebring kan word - min of meer tot aan die einde van die eerste gedeelte van die roman op bladsy 159, waar Vos saam met Nellie wegtrek van die verwoeste Alleen om op die dorp te gaan bly. Hierna begin die "vreemde" tweede deel van die roman waar Vos, na 'n lang meditasie, op 'n peregrinasie deur die land vertrek om sy "boodskap" aan die inwoners oor te dra. Hy reis eers per donkiekar, maar keer na 'n tyd terug na die dorp waar hy 'n nag oorslaap, Nellie briesend agterlaat, en dan sy tog te voet voortsit. Die teks wat op 
hierdie deel van toepassing is, is ' $n$ Australiese roman, naamlik Patrick White se Voss (1957).

\section{Voss}

Weereens spreek die klankooreenkoms tussen die twee titels vanself. Daar kan ook 'n verband gelê word tussen die name van die protagoniste in Voss en Faust: Heinrich in Faust en Johann Ulrich Voss in Voss (die "Johann" kan ook as verwysing na Johann Wolfgang von Goethe gelees word).

In Patrick White se Voss word vertel hoe die hoofkarakter, Johann Ulrich Voss, in die negentiende eeu 'n ontdekkingsreis deur die Australiese binneland onderneem - 'n tog waarvan die eintlike doelwit baie vaag bly. Voss slaan 'n baie eienaardige figuur in die Australiese landskap, in die eerste plek omdat hy Duits, 'n vreemde taal, praat, maar ook omdat hy vreemd optree. Die ander karakters in die roman vind hom ongemaklik (p. 10,62), ongemanierd (p. 26, 72-73), koud (p. 89), hooghartig (p. 23) en waansinnig (p. 27, 35).

Voss is egter die sentrum van die roman waarteen die res van die komponente van die roman - die Australiërs en die landskap - in verskillende posisies te staan kom. Met betrekking tot die ander karakters, kan die roman in 'n groot mate voorgestel word as die uitbeelding van 'n siftingsproses waartydens Voss hom teen hierdie karakters opstel om 'n waardige teenstander of gelyke te vind. Die lang reis deur die binneland funksioneer as agtergrond waarteen die verskillende karakters een vir een hul swakhede openbaar.

Die jong man, Harry Robarts, plaas homself reg van die begin af in die posisie van onderdanige teenoor Voss (p. 31-32). Die natuurkundige, Palfreyman, openbaar homself as geestelik verlore, omdat hy 'n emosionele skuldverband met sy suster het wat hy nooit sal kan delg nie (p. 264). As Christus-figuur en verteenwoordiger van die konvensionele Europese religieuse geloof (p. 242) is Voss nie opgewasse teen die Australiese binneland nie en word hy dan op gepaste wyse vermoor deur inboorlinge terwyl hy met hulle probeer kommunikeer (p. 342-343). Frank Le Mesurier kan beskou word as die verteenwoordiger van die Europese kreatiewe tradisie (hy skryf gedigte in 'n notaboek - p. 294-297). Ook Frank is nie opgewasse teen die Australiese werklikheid nie en pleeg uiteindelik selfmoord (p. 381). Judd, die geharde voormalige misdadiger, misluk ook, omdat hy te pragmaties ingestel is en besluit om Voss agter te laat en terug te keer na die beskawing, eerder as om in die wildernis te sterf (p. 243, 346). Nie een van hierdie karakters het dus 
die uithouvermoë, die wil, en die belangrikste van alles, die visie, wat Voss aanvuur nie.

Die enigste karakter wat van die ander onderskei kan word, is Laura Trevelyan. Sy is as weeskind aangeneem deur haar moeder se suster, Mrs. Bonner. Haar buitestandersposisie maak dit vir haar moontlik om onmiddellik vir Voss na waarde te skat. Volgens haar behoort die land aan hom, omdat, soos sy sê: "It is his by right of vision"” (p. 29). Uit die twee gesprekke tussen Voss en Laura, is dit duidelik dat hulle mekaar verstaan (p. 68-70, 87-91). Wanneer Voss op die ekspedisie vertrek, bly hulle kontak behou, eers deur briewe (p. 153, 185, 215, 237) waarvan slegs die eerste twee hul bestemming bereik - en later (belangriker) deur drome (p. 140) en veral visioene (p. 163-164, 192, 198-199, 250, 275, 358, 363-364, $367,383,393)$.

By hierdie onkonvensionele band wat tussen Voss en Laura ontwikkel, soos ook by die interaksie tussen Voss en die ander karakters, is die Australiese landskap as stille medespeler betrokke. Hierdie landskap vorm die uiteindelike agtergrond van die verhaal van 'n siele-avontuur - dit is wat Voss wesenlik is. Dié landskap word deurgaans as 'n metafisiese, geestelike ruimte voorgestel, wat veral gesuggereer word deur die ligbeelde wat gebruik word in die beskrywings van die landskap en waar "nederige" objekte uit die omgewing met spirituele inhoud gelaai word (p. 123; sien ook p. 45, $68,87,128,155-156,172,259,329,364,376)$.

'n Verband tussen die landskap of ruimte aan die een kant en die geestelike aan die ander kant word veral gesuggereer deur die gebruik van ligbeelde by beskrywings van die karakters, soos blyk in die volgende beskrywing van Voss:

The trapped crow stalked out. Although rusty and crumpled, he had triumphed, and the last blaze of evening light will help enlarge most objects to heroic proportions. The man would be ludicrous, Laura saw, if it were not for his arrogance; this just saves him, terrible though it is. His eyes were glittering with it in the mineral light of evening (p. 73; sien ook p. 16, 90, 358, 383, 386).

Die ekspedisie wat Voss deur die binneland onderneem, is dus eintlik 'n geleentheid waar 'n spirituele drama afspeel, waar die sielelig van die mense, veral dié van Voss, in kontak gebring word met dié van die Australiese landskap. Dit is 'n proses waar verandering en groei kan plaasvind, wat Voss byna profeties verwoord met die woorde: "To make yourself, it is also necessary to 
destroy yourself,' said Voss" (p. 34). In hierdie woorde kan 'n ingesteldheid herken word wat soortgelyk is aan dié waardeur Faust aangevuur is.

Voss begin die roman as 'n hooghartige, arrogante persoon wat homself as 'n soort selfgenoegsame god beskou (p. 15, 34, 50, 144, 175), maar hy eindig uitgeteer op die grond, oorgelaat aan die genade van die Australiese inboorlinge. Voor sy kop deur een van sy inboorling-helpers, Jackie, afgesny word, ervaar hy hierdie toestand van hom egter as soortgelyk aan dié van 'n heilige (p. 389) en daar stu 'n nederigheid in hom op, sodat hy Christus om redding smeek (p. 390). Soos Faust voor hom, word hy aan die einde wel gered, ten spyte van 'n "bose" lewe.

In 'n artikel waar die ekspedisie ook gesien word as 'n geleentheid waartydens die karakters (Voss boweal) hul idees oor hulself en die wêreld meet teen hul eie "stubborn nature and outside reality", sonder Norbert Platz die ingesteldheid waarmee Voss die Australiese landskap benader uit deur dit "exuberant idealistic egotism" te noem (Platz, 1984:173-174). Met hierdie benoeming assosieer hy Voss aan die een kant met die Duitse geesteswêreld waaruit Faust voortgekom het en plaas hy Voss aan die ander kant teenoor Mr. Bonner, die Australiese besigheidsman, wat die ekspedisie befonds en wat met pragmatiese Engelse utilitarisme geassosieer word. Platz se betoog maak dit duidelik dat die Duitse herkoms en agtergrond van Voss spesifiek betekenisvol is.

Voss se Duitse herkoms maak van hom 'n "suiwer" verteenwoordiger van 'n ekstreme soort metafisiese idealisme. Die gebruik van so 'n "onverdunde" idealisme in die roman lei tot die opheffing van die grens tussen teenoorgesteldes - "gees" (Voss) en "vlees/materiële" (landskap) - sodat 'n situasie ontstaan waar "kommunikasie" kan plaasvind tussen die materiële en die geestelike, met as ongewone resultaat dat "mind is questioned by matter" (Platz, 1984:175). Twee van die belangrikste uitvloeisels van hierdie proses is volgens Platz in die eerste plek dat die roman wys hoe dit moontlik is "to hold spiritual intercourse with the landscape" en, gepaard hiermee, lei dit in die tweede plek daartoe dat "the continent gains in metaphysical significance" (Platz, 1984:175).

Voss se "waansinnige" tog die onbekende in lei dus nie slegs tot sy persoonlike redding nie, maar ook tot 'n verryking van die Australiese ruimte of werklikheid. Hierdie verrykings geskied op 'n soortgelyke manier as wat Faust se "duiwels-geïnspireerde" optrede 
in Faust deur die "dialektiek van die bose" tot vooruitgang en verryking van die Europese wêreld lei.

Voss kan dus - as uitbeelding - gesien word as deel van die proses waardeur die Europese kultuur en subjektiwiteit moes gaan om 'n adekwate psigiese ingesteldheid teenoor die "nuwe" landskap van Australië te ontwikkel. Die teks kan ook gesien word as 'n rekord of indeks van die manier waarop die Europese geestesingesteldheid kennis geneem het van die Australiese landskap, daarop reageer het, verander is, en uiteindelik ook deel geword het van die nuwe werklikheid. Die benadering van Voss se tog die Australiese binneland in - op hierdie manier as 'n konfrontasie tussen menslike spiritualiteit en materiële landskap - dien sigself duidelik aan as ' $n$ raamwerk waarbinne veral die laaste gedeelte van Vos geplaas kan word. Die manier waarop Europese setlaars uiteindelik in die Australiese landskap leer leef het en 'n "tuiste" gevind het, word ook só betrek.

Dit is veral die verskille tussen die twee romans, die Australiese Voss en die Afrikaanse Vos, wat in hierdie opsig betekenisvol raak. As die uitbeelding van Voss se reis as 'n sekere posisie op 'n "indeks" gelees word, dui 'n vergelyking tussen Voss en Vos aan dat Vos van 'n dieper en meer fundamentele geworteldheid in die SuidAfrikaanse landskap spreek, as wat Voss dui op 'n geworteldheid in die Australiese landskap.

Reeds die korter naam van die Afrikaanse roman druk al iets uit van hierdie verskil - van 'n meer gestroopte, maar tegelykertyd meer gevestigde, outentieke verhouding tussen karakter en landskap. In baie opsigte is die uitbeelding van die Suid-Afrikaanse landskap in Vos veel meer alledaags en besadig, veel minder dramaties as die uitbeelding in Voss. Hierdie kan 'n manier wees om uitdrukking te gee aan die vanselfsprekendheid waarmee Vos se Afrikaanse karakters die landskap beset.

In baie opsigte lees die uitbeelding van Vos se reis in Vos soos 'n (komplekse) parodie van Voss se reis. Waar die doelwit van Voss se reis is om die omvang van sy "ryk" en die sterkte van sy wil vas te stel, is dié van Vos veel nederiger - hy wil bloot sy "boodskap" van selfaflegging aan die mense op die platteland bring. By die Australiese Voss se reis staan sy (idealistiese, egoïstiese) waardestelsel skerp afgeteken teen dié van die inheemse mense. Hy beskou hulle op 'n bepaalde hubristiese oomblik selfs as sy "onderdane" (p. 189, 273, 334-335). In die Afrikaanse Vos word die belangrikste teenstelling op Vos se reis nie gevorm deur 'n 
teenstelling tussen Europese en inheemse kulture nie, maar tussen mense wat aan dieselfde kultuurgroep behoort - dus tussen Vos en sy "eie" mense, die boere en hul vrouens op die plase waar hy aandoen. Vos se reis is 'n ontdekking van hoe skaars sy soort toegewyde geloof is in die land. Wat hy vind, is dat al die witmense aan wie hy sy boodskap oordra, "bybedoelinge" het (p. 229): hulle is almal normale mense wat Vos op hul verskillende maniere sien as 'n geleentheid om hul veelvuldige, menslike behoeftes en begeertes te bevredig.

Vos kry te make met 'n sosiale landskap waarin pragmatiese en alledaagse sake voorrang geniet bo 'n idealistiese of konsekwente godsdienstige ingesteldheid. Dit is te verstane dat sy boodskap van selfaflegging en begeerteloosheid nie juis entoesiasties ontvang sal word nie. In Vos word die idealisme van die hoofkarakter getemper en gestuit deur 'n landskap wat in die eerste plek sosiaal van aard is. Die hoof-teenspeler van Voss se grootheidswaan in Voss is die materiële Australiese ruimte. Hierdie "omruiling" is ook te sien in die manier waarop die twee protagoniste aan hul eindes kom: Voss aan die hand van die mense in die ruimte, wanneer sy kop deur die inboorling, Jackie, afgesny word, en Vos aan die hand van die natuur, wanneer hy aan die einde verkluim.

'n Mens sou kon sê dat Vos veel minder dramaties en "ernstig" is as Voss. Voss se konfrontasie met die Australiese binneland begin met 'n groot, goed toegeruste ekspedisiespan. Vos se peregrinasie begin egter op sy donkiekar, met sy twee poepende gunstelingmuile voor die kar gespan (p. 182). In albei romans is daar 'n briefwisseling tussen die hoofpersoon en 'n vroulike karakter - in Voss tussen Voss en sy latere "Intended", Laura; in Vos tussen Vos en Nellie, sy vrou. In Voss skryf die karakters oor metafisiese onderwerpe, soos wil, visie en geloof, maar in Vos is die onderwerpe veel meer alledaags: Annie se waarnemings, emosies, familiesake en ontluikende verhouding met 'n wewenaar.

Vos se konfrontasie met die Afrikaanse "landskap" is ook minder dramaties, omdat die teenstelling tussen die "groepe" in die ruimte nie so fel is in Vos as in Voss nie. Terwyl die inboorlinge in hul rol as Voss se teenspelers deurgaans vreemd en onverstaanbaar geteken word, is Vos se teenspelers, die mense op die eensame plase, nie ver van Vos verwyder wat betref hul wêrelduitkyk en kulturele gebruike nie. Die nabyheid van die twee "groepe" in Vos - die "ongelowige" praktiese mense aan die een kant en die "gelowige" geïsoleerde Vos aan die ander kant - is een van die belangrikste 
redes waarom daar in Vos veel meer sprake is van 'n humoristiese aanslag as in Voss. Wat in Vos se oë as "afvalligheid" verskyn, is van buite af gesien as aspekte en optredes van mense wat juis hul "menslikheid" beklemtoon en waarmee die leser kan empatiseer met 'n glimlag op die gesig.

Ook wat betref die sentrale aspek van die konfrontasie van die twee betrokke protagoniste met die landskap, naamlik spiritualiteit, is daar belangrike verskille tussen die twee tekste. Dit kan wesenlik neerkom op 'n klemverskuiwing. Die aard van die spiritualiteit wat geleidelik op die voorgrond tree in Vos, is veel minder "abstrak" as dié in Voss. Een manier waarop spiritualiteit ter sprake kom in Voss, is by die uitbeelding van sy interaksie met die inheemse mense. Voss is in hierdie verband belangwekkend, omdat White Voss uitbeeld asof hy soos die inheemse mense word, "regressing into a way of mythic thinking which he shares with the Aborigines" (Platz, 1984:175). Voss se interaksie met die inheemse, sosiale werklikheid van Australië kom ook tot 'n dramatiese eindpunt in 'n "simboliese" voltooiing wanneer hy deur Jackie, een van sy voormalige helpers, doodgemaak word en sy kop afgesny word (p. 394). Die dominansie van die Europese rasionalistiese wêrelduitkyk waarvan Voss 'n eksemplariese verteenwoordiger is, kry met hierdie "gebaar" die finale slag, sodat Voss uiteindelik "tuiskom" in die vreemde - minus sy kop. Vir die "onaangepaste" Europese denke waarmee Voss sy reis begin het, dui hierdie uitbeelding op die enigste manier waarop die Europese mens vat kan kry op die Australiese werklikheid - deur dit wat "irrasioneel" voorkom, te aanvaar as onlosmaaklik deel van die nuwe ruimte waarin hy hom bevind.

In Vos gaan Vos deur 'n soortgelyke suiwerings- en stropingsproses en dit eindig ook met sy "tuiskoms", maar hier is dit heelwat minder dramaties. Die feit dat die uitbeelding van hierdie proses meer konkreet is, dra ook daartoe by dat die teenstellings in die roman minder fel en dramaties is as in Voss. Soos in die geval van Voss, word Vos se tuiskoms gekoppel aan interaksie met mense wat nakomelinge is van die inheemse of oorspronklike inwoners van die land. Die laaste oorstaanpunt op Vos se reis is Middelpos se lokasie, waar hy 'n paar dae saam met Outa Arrie Witbooi deurbring in sy "pondok". In die tyd wat hy hier deurbring, besef hy dat sy boodskap hier nie nodig is nie, en dat hy, Vos, by Arrie moet leer (p. 236-237). Wat hy hier leer, is dat die toestand waarna hy gestreef het en die verlossing waarna hy gesmag het, in "eenvoud" te vinde is (p. 240). 
Vos se spirituele bevryding en tuiskoms vloei dus voort uit 'n heel rustige en besadigde interaksie met ander mense in die landskap. Dit is nie so dramaties en gewelddadig soos die uitbeelding in Voss nie. Nog ' $n$ rede waarom die uitbeelding minder gewelddadig is, is omdat Vos 'n later fase uitbeeld in die interaksie tussen setlaars en inheemse mense. Die geweld wat in Voss uitgebeeld word, lê in die verre verlede, soos die kortlikse verwysing na die "guerilla-oorlog ... tussen wittes, die bruines en die geles van die Rôeveld" aandui (p. 234). Vos se verblyf by Outa Arrie word ook gekenmerk deur 'n vreedsaamheid en 'n hoë graad kommunikasie - anders as Voss se verhouding met die Australiese inboorlinge.

Vos bring ook 'n verdere ontwikkeling met betrekking tot Voss in die manier waarop Vos se dood uitgebeeld word. Voss se dood is gewelddadig en te wyte aan mense, terwyl die dood wat Vos uiteindelik sterf rustig en vreedsaam is en te wyte is aan die natuur. Hy verkluim naamlik wanneer hy, direk teen die raad van Outa Arrie en Mister Fischer, die terugtog huistoe aanpak en in 'n sneeustorm vasgevang word (p. 247-249).

Twee voorlopige opmerkings kan gemaak word by 'n lesing van Vos met Voss as agtergrond: Die eerste handel oor die beelde van die verhouding(s) van Europees-gewortelde kulture met "inheemsheid" wat in die twee tekste uitgebeeld word, en die tweede is die uitbeelding van die verhouding tussen die betrokke kulture en die natuur van die onderskeie ruimtes.

In die geval van die verhouding tussen die Afrikaanse (Europese) kultuur en die inheemse kultuur, dui Vos op 'n noue en selfs intieme verband. Uit die interaksie tussen Vos en Outa Arrie is dit duidelik dat daar sprake is van 'n groot mate van op-mekaar-aangewesewees, onderlinge insig en respek by verteenwoordigers van die twee kultuurgroepe. Dit is ook duidelik dat die inheemse kultuur 'n groot mate van voorrang geniet bo die "ortodokse" Europese kultuur. Wat die verhouding tot die natuur betref, ontwikkel die protagoniste in albei tekste 'n nederige onderdanigheid teenoor die natuur. In die geval van Vos kan egter bygevoeg word, dat die band tussen karakter en natuur veel meer "intiem" en intens is as in Voss.

Die beskrywing van Vos se dood is 'n veel "aangenamer" en "gemakliker" geleentheid as Voss se dood. By Voss se dood oorheers "onplesierige" gewaarwordings, soos die reuk van die ontbindende lyk van Harry wat langs hom lê ( $p$. 388), die hitte (p. 389), die reuk van die dansende inboorlinge (p. 391) en die slagting van die perde en muile (p. 391-392). By Vos se dood, 
daarenteen, oorheers die koue (p. 248). Vos word ook lomerig en droom en hy ervaar die sneeu wat uiteindelik begin val as "betowerend" (p. 248).

Die belangrikste verskil tussen Vos en Voss hou egter verband met die aard van hulle bewussyn, en daarmee saam, die verlossingstradisie wat hulle in hul laaste oomblikke aanroep. Voss word uiteindelik so nederig deur sy konfrontasie met die Australiese landskap, dat hy sover kom om hom op Christus se genade te beroep (p. 390). By die uitbeelding van Vos se laaste oomblikke is suggesties dat sy bewussyn buite die ortodoks-Christelike beweeg. Vos ervaar 'n soort regressie, wat die idee van reïnkarnasie aktiveer - 'n idee wat ook elders in die roman figureer (vgl. p. 53, 208, 218). Hierdie idee word verder versterk wanneer beskryf word hoe die haakspelde wat sy jas toehou, oopbars wanneer hy gaan lê (p. 249). Een ding waarmee haakspelde geassosieer kan word, is babadoeke. Die baba-konnotasie word verder versterk deur die verwysing na die moment van konsepsie wat hy aanskou (p. 248) en die fetale posisie waarin hy uiteindelik sterf (p. 249). Hierdie aktivering van 'n (her)geboorte-motief op hierdie moment van die roman, plaas egter Vos se sterfte en uiteindelike verlossing - anders as dié van Voss - buite die sfeer van die ortodoks-Christelike.

Platz interpreteer die uitbeelding van Voss se konfrontasie met die Australiese landskap as 'n "geestelike verryking" van die landskap. Net so sou die uitbeelding in Vos gelees kon word as 'n kartering van die verhouding tussen (Afrikaanse) spiritualiteit en die "nuwe" Suid-Afrikaanse ruimte. Vos suggereer in hierdie verband uiteindelik dat die ortodoks-Christelike spiritualiteit nie voldoende is om in die Afrika-konteks ' $n$ volwaardige, spirituele verhouding met die landskap te fundeer nie. Die roman suggereer dat slegs wanneer die ortodoks-Christelike aangepas of aangevul word met geestelike tradisies en sienings buite-om die ortodoks-Christelike, 'n volwaardige verhouding met die Afrika-wêreld moontlik word.

Vos bring ook die interessante gedagte dat so 'n wyer ingesteldheid wel reeds in die Afrikaanse gemeenskap gerealiseer het. Twee vorms van so 'n wyer (ander) ingesteldheid is eerstens die pragmatiese ingesteldheid van die plaas- en dorpsbewoners met wie Vos te doen kry en tweedens Vos se ingesteldheid, wat bestaan uit 'n samevoeging van die ortodoks-Christelike (of 'n konsekwente uitlewing van so 'n ingesteldheid), elemente uit die apokriewe en die gnostiek. Op hierdie vlak is daar weer 'n betekenisvolle ooreenkoms tussen Vos en Voss in die manier waarop Voss met ligbeelde geassosieer word. Soos vroeër betoog, sal 'n lesing van Vos nie 
volledig wees as dit nie aandag gee aan die Gnostiese idee van "die man van lig" nie.

\section{5. $\Phi \omega ́ s$}

Net soos by die vorige afdelings, speel klankooreenkoms 'n belangrike rol by die verbandlegging tussen Vos en 'n ander teks of tekste. In die geval van die Gnostiese "man van lig", lê die

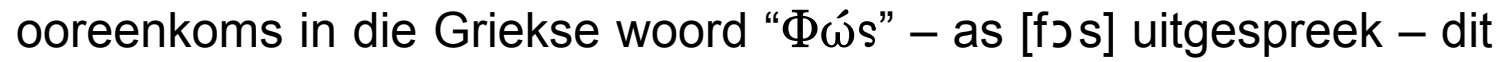
wil sê dieselfde as die titel van die roman, Vos, en dié van die naam van die hoofkarakter, Vos. In die roman is daar op twee plekke regverdiging vir so 'n verbandlegging. Op p. 36 meen die Boesman, Hans Bokpoot, dat Vos op 'n spesiale manier gebore is, naamlik "Van die lig uit" (p. 36) en op p. 115 wonder Vos of die Duiwel waarmee hy te doen gekry het, nie "'n engel van die lig" was nie (p. 115). Soos vroeër aangedui, word Vos self met hierdie Duiwel geïdentifiseer.

In die gnostiese tradisie is "die man van lig" die gedaante waarin die gelowige deur daadwerklike inisiatief die greep van die aardse ontsnap en met God herenig word. Die "man van lig" in die gedaante van die $\Phi \omega \dot{s}$, word onderskei van die Adam, die man van klei, van die aarde (Hedsel, 1998:94-95; 262-263). Sommige kenners meen verder dat " $\Phi \omega \varsigma^{\prime}$ ", afhangende van hoe die klem geplaas word, sowel lig as man kan beteken (Doresse, 1960:101; Hedsel, 1998:386; nota 14). Die idee verskyn ook in 'n ander vorm in die Evangelie volgens Philip, waar die gnostiese gelowige 'n "kleed van lig" aantrek (Layton, 1987:348).

Soos in die geval van die ander tekste waarmee Vos in hierdie artikel in verband gebring is, kom betekenis juis voort uit afwykings van die bron- of subtekste. Vos word nie aangebied as 'n "doktrinêre" man van lig nie, maar as 'n "gerelativeerde" een. Net soos in die geval van die verhouding tussen Vos en Job, en Vos en Voss, word die idee van die man van lig nie simplisties "ernstig" opgeneem in Vos nie. Hierdie ontluistering vind plaas deur die manier waarop die beeld of simbool van die swaap, die nar of die idioot in die teks funksioneer.

Ofskoon Vos in die tweede gedeelte van die roman gesien kan word as 'n "man van lig" wat ontsnap het van die magte van die duisternis en 'n spirituele ontwaking ondergaan het, verskyn hy in hierdie gedeelte van die roman terselfdertyd ook in die gedaante van die "dwaas". Een van die bekendste vorme waarin die dwaas 
tradisioneel verskyn, is as 'n verflenterde reisiger wat sy besittings aan 'n stok oor sy skouers dra (Cirlot, 1978:10-111). Vos reis eers per donkiekar, maar later te voet (p. 192 e.v.). Hy raak ook opvallend gehawend en onversorg, soos duidelik is wanneer hy van een van sy peregrinasies terugkeer (p. 193). Die "dwaas"-beeld word ook in die teks self gesuggereer, byvoorbeeld wanneer Vos tydens die laaste skof van sy reis in 'n sneeustorm vasgevang word. Terwyl hy in 'n vlak grotjie lê, hallusineer hy en sien hy sy eie "ontvangenis", waar spermselle op 'n eiersel afstorm om dit te penetreer: "Voor is daar 'n vinnige, 'n maere: bietjie slim en sterk, maar dwaas ook" (p. 248).

Vos se besluit om die terugtog vanaf Middelpos aan te durf terwyl 'n sneeustorm duidelik dreig, is natuurlik ook 'n dwase daad. Die resultaat is egter 'n heel pregnante beeld, dié van die voormalige duiwelse Vos, met sy spirituele peregrinasie volvoer, onbeweeglik in sneeu en ys vasgevang. Dit is ' $n$ beeld waarin die teenoorgesteldes waarmee die roman werk, naamlik die goeie en die bose, die spirituele en die sondige, die verstandige en die dwase, met mekaar verenig word. Die man van lig is nie net spiritueel voltooi nie, maar ook 'n dwaas. Ten spyte van die wye kennisname van idees oor spirituele ontwaking en verlossing, bly die karakter Vos in die roman uiteindelik God se nar.

\section{Slot}

Die beeld van die spiritueel-ontwaakte Vos wat as 'n dwaas in die sneeu sterf, gee duidelik uitdrukking aan die sentrale onderwerp (of paradoks) van Anna M. Louw se kuns. Ten spyte van die feit dat Vos duidelik blyke gee van 'n wyd-strekkende kennisname van idees oor spirituele ontwaking en verlossing, bly die karakter Vos in die roman uiteindelik God se nar. Mens sou wou byvoeg dat daar waarskynlik rede is om te dink dat hier ook 'n beeld van die outeur af te lese is. Wanneer die leser homself of haarself by dié beeld insluit, kry 'n roman soos Vos sy ware of eintlike betekenis.

\section{Geraadpleegde bronne}

CIRLOT, J.E. 1978 [1962]. A dictionary of symbols. Londen: Routledge \& Kegan Paul.

DORESSE, JEAN. 1960. The secret books of the Egyptian Gnostics: An introduction to the Gnostic Coptic manuscripts discovered at Chenoboskion. Londen: Hollis \& Carter.

GOETHE, JOHANN WOLFGANG VON. s.a. [1808, 1833]. Faust. Eine Tragödie. Erster und zweiter Teil. München: Goldmann. 
GOETHE, JOHANN WOLFGANG VON. 1966. Faust. I. Kaapstad: Nasionale Boekhandel. (In Afrikaans vertaal deur Eitemal.)

GROSHEIDE, F.W., LANDWEHR, J.H., LINDEBOOM, C. \& RULLMANN, J.C., reds. 1925. Christelijke encyclopædie voor het Nederlandsche volk. Kampen: Kok.

HEDSEL, MARK \& OVASON, DAVID. 1998. The Zelator: A modern initiate explores the ancient mysteries. Londen: Century.

LAYTON, BENTLEY. 1987. The Gnostic scriptures. Londen: SCM.

LOUW, ANNA M. 1999. Vos. Kaapstad: Human \& Rousseau.

PLATZ, NORBERT H. 1984. The Western consciousness of novel writing and the image of Australia in Patrick White's Voss. World Literature written in English, 24(1):170-177.

VAN ZYL, IA. 1990. lets van 'n uilskuiken: 'n Gids tot Anna M. Louw se oeuvre. Pretoria: HAUM-Literêr.

WEICH, F., red. 1994. Die boek van Henog. Mosselbaai: Libanon-uitgewers.

WHITE, PATRICK. 1957. Voss. Harmondsworth: Penguin.

\section{Kernbegrippe:}

Afrikaanse roman

Faust-legende

Gnostiek

Job

\section{Key concepts:}

Afrikaans novel

Faust legend

Gnosticism

Job 